\title{
Herpes Simplex Virus Linked to Alzheimer’s Disease
}

\section{Shi-Bin Cheng*}

Shi-Bin Cheng, Department of Pediatrics, Women and Infants Hospital, Alpert Medical School, Brown University, Providence, RI 02903, USA

Herpes simplex virus (HSV) is a neurotropic double-stranded DNA virus which includes the HSV-1 and HSV-2 subtypes. HSV is composed of an inner DNA core, a capsid (e.g. VP22), the tegument, and an outer envelope, which is a lipid membrane containing glycoproteins. HSV1 infects $60-80 \%$ of people worldwide and causes infectious corneal blindness, the common cold sore and potentially fatal encephalitis $[1,2]$. HSV is one of the leading infectious viral pathogens found in immunocompromised hosts, such as transplant recipients [3]. HSV induces tissue damage including cell infiltration, perivascular inflammation and syncytial formation [3]. HSV initially infects the epithelial cells and then enters the sensory nerve terminals. During its life cycle in the sensory nervous system, HSV travels by retrograde transport to the neuronal cell bodies in the trigeminal ganglia, and then either enters latency or replicates. Replicated or reactivated HSV travels by anterograde transport out of the cell body to the central nervous system in addition to the peripheral mucosal membrane.

Alzheimer's disease $(\mathrm{AD})$ is a progressive neurodegenerative disease leading to the irreversible loss of neurons and the loss of intellectual abilities, including memory and cognition. According to the National Institute on Aging, AD afflicts 2.5-4.5 millions Americans and 18 million people worldwide. $\mathrm{AD}$ is pathologically characterized by intracellular neurofibrillary tangles and extracellular senile plaques. While the pathogenesis of $A D$ is still elusive, it is widely recognized that APP plays a central role in the pathogenesis of AD based on the following evidence: i) APP is the precursor to beta-amyloid peptide (Abeta), a main constituent of senile plaques which causes cell death, synaptic defects and memory impairment [4-9]; ii) Disruption of APP-mediated axonal transport contributes to the neurodegeneration associated with $\mathrm{AD}$ [10]; iii) Aberrant APP phosphorylation results in Abeta production, cell stress and degeneration [10-12]

RT-PCR studies reveal the existence of HSV-1 DNA in plaques of frontal and temporal cortices in post-mortem brains of both sporadic and familial Alzheimer's disease [13-16]. The presence of HSV-1 in the brain is considered to be a risk factor for $\mathrm{AD}$ in elderly people who carry the apolipoprotein E $\varepsilon 4$ allele [17]. Viral proteins of HSV1 interact with many $\mathrm{AD}$ susceptibility genes or proteins [18]. In addition, epidemiological study demonstrates that HSV-1 reactivation, as measured by seropositive $\operatorname{IgM}$, is a high risk factor for $\mathrm{AD}$ and that HSV-1 chronic infection contributes to the progressive brain damage characteristic of $\mathrm{AD}$ [19]. A more recent similar study shows that antiHSV IgG antibody avidity is higher in AD patients and much higher in subjects with amnestic mild cognitive impairment (a prodromal stage of $\mathrm{AD}$ ) than in controls, suggesting that seropositve IgG could be adopted as a biomarker for early diagnosis of amnestic mild cognitive impairment as well as AD [20]. These data suggest a link between HSV infection and $\mathrm{AD}$ pathogenesis. There have been numerous studies focused on deciphering the mechanisms behind this link.

A plethora of evidence shows that HSV-1 infection affects APP proteolytic processing, transport, phosphorylation and distribution [21-27]. A viral envelope glycoprotein B (gB) contains a sequence homologous to the carboxyl-terminal region of Abeta, a cleavage product of APP [21]. A peptide derived from gB accelerated the formation of Abeta fibrils which were toxic to primary cortical neurons
[21]. Acute HSV-1 infection affects APP proteolytic processing both in vitro $[21,22]$ and in vivo [23]. APP is co-isolated with HSV particles from HSV-1-infected Vero cells and isolated HSV-APP particles are able to transport in squid axon when injected into squid axon, suggesting a role of APP in mediating viral transport [25]. Further experiments in our lab have confirmed the co-localization of HSV-1 particles with APP inside cells under epifluorescent and electron microscopes [26]. A time-lapse live confocal imaging reveals that HSV-1 particles travel together with APP inside living cells [26]. This dynamic interaction between HSV-1 and APP results in pathological consequences: HSV-1 infection decreases the average velocity of APP vesicles and causes APP mal-distribution in infected cells [26].

Compromised transport and mis-localization of APP could contribute to increased APP proteolysis with HSV-1 infection [24], which may consequently cause cellular injury. In addition, HSV-1 infection of human neuronal cell line increases the phosphorylation of tau proteins, the main component of neurofibrillary tangles, one of the hallmarks of $\mathrm{AD}$ [28]. A viral kinase, UL13, which phosphorylates HSV-1 VP22, may phosphorylates human tau proteins [16]. Moreover, treatment of HSV-1-infected cells with acyclovir, the main antiviral agent used for treating HSV-1 infection by targeting viral DNA replication, substantially decreases the amount of Abeta and phosphorylated tau protein, two culprits of AD [29]. This finding not only supports the concept that HSV infection is involved in AD pathogenesis, but also opens up a novel window to slow or stop the progression of $\mathrm{AD}$ with antiviral strategies.

Collectively, HSV-1 infects a wide range of neurons and epithelial cells and transports bidirectionally in neurons and epithelial cells. HSV functions as intact functional machinery actively usurping a variety of cellular biological machineries by interacting with cellular proteins for its entry, transcription, DNA replication and egress. HSV infection and repeated reactivation result in the hyper phosphorylation of tau proteins as well as the disturbance of biogenesis, subcellular localization, phosphorylation and proteolytic processing of APP. Given the prevalent infection of HSV among people worldwide, the link of chronic HSV infection to AD and the potential use of HSV as a delivery vector for gene therapy, it is imperative to dissect the mechanisms for interaction between HSV and cellular proteins that are associated with $\mathrm{AD}$. Clinical trials for evaluating the efficacy of antiviral drugs in the treatment of $\mathrm{AD}$ are urgently needed.

*Corresponding author: Shi-Bin Cheng, Department of Pediatrics, Women and Infants Hospital, Alpert Medical School, Brown University, USA, Tel: +1-401-2741122, Ext. 8007; E-mail: shibin_cheng@brown.edu

Received January 03, 2013; Accepted January 03, 2013; Published January 05 , 2013

Citation: Cheng SB (2013) Herpes Simplex Virus Linked to Alzheimer's Disease. J Trop Dis 1: e103. doi:10.4172/2329-891X.1000e103

Copyright: (c) 2013 Cheng SB. This is an open-access article distributed unde the terms of the Creative Commons Attribution License, which permits unrestricted use, distribution, and reproduction in any medium, provided the original author and source are credited. 


\section{References}

1. Cunningham AL, Diefenbach RJ, Miranda-Saksena M, Bosnjak L, Kim M, et al (2006) The cycle of human herpes simplex virus infection: virus transport and immune control. J Infect Dis 194: S11-S18.

2. Diefenbach RJ, Miranda-Saksena M, Douglas MW, Cunningham AL (2008) Transport and egress of herpes simplex virus in neurons. Rev Med Virol 18: 35-51.

3. Shin KC, Park CG, Hwang ES, Cha CY (2008) Human cytomegalovirus IE1 protein enhances herpes simplex virus type 1-induced syncytial formation in U373MG cells. J Korean Med Sci 23: 1046-1052.

4. Selkoe DJ (2001) Alzheimer's disease: genes, proteins, and therapy. Physiol Rev 81: 741-766.

5. Selkoe DJ (1999) Translating cell biology into therapeutic advances in Alzheimer's disease. Nature 399: A23-A31.

6. Selkoe DJ (2004) Cell biology of protein misfolding: the examples of Alzheimer's and Parkinson's diseases. Nat Cell Biol 6: 1054-1061.

7. Hoozemans JJ, Chafekar SM, Baas F, Eikelenboom P, Scheper W (2006) Always around, never the same: pathways of amyloid beta induced neurodegeneration throughout the pathogenic cascade of Alzheimer's disease. Curr Med Chem 13: $2599-2605$

8. Wirths O, Multhaup G, Bayer TA (2004) A modified beta-amyloid hypothesis: intraneuronal accumulation of the beta-amyloid peptide--the first step of a fatal cascade. J Neurochem 91: 513-520.

9. LaFerla FM, Green KN, Oddo S (2007) Intracellular amyloid-beta in Alzheimer's disease. Nat Rev Neurosci 8: 499-509.

10. Stokin GB, Lillo C, Falzone TL, Brusch RG, Rockenstein E, et al. (2005) Axonopathy and transport deficits early in the pathogenesis of Alzheimer's disease. Science 307: 1282-1288.

11. Lee MS, Kao SC, Lemere CA, Xia W, Tseng HC, et al. (2003) APP processing is regulated by cytoplasmic phosphorylation. J Cell Biol 163: 83-95.

12. Muresan Z, Muresan V (2007) The amyloid-beta precursor protein is phosphorylated via distinct pathways during differentiation, mitosis, stress, and degeneration. Mol Biol Cell 18: 3835-3844.

13. Jamieson GA, Maitland NJ, Wilcock GK, Craske J, Itzhaki RF (1991) Laten herpes simplex virus type 1 in normal and Alzheimer's disease brains. J Med Virol 33: 224-227.

14. Mori I, Kimura Y, Naiki H, Matsubara R, Takeuchi T, et al. (2004) Reactivation of HSV-1 in the brain of patients with familial Alzheimer's disease. J Med Virol 73: $605-611$.

15. Wozniak MA, Mee AP, Itzhaki RF (2009) Herpes simplex virus type 1 DNA is located within Alzheimer's disease amyloid plaques. J Pathol 217: 131-138.
16. Ball MJ, Lukiw WJ, Kammerman EM, Hill JM (2012) Intracerebral propagation of Alzheimer's disease: Strengthening evidence of a herpes simplex virus etiology. Alzheimers Dement.

17. Itzhaki RF, Wozniak MA (2006) Herpes simplex virus type 1, apolipoprotein $\mathrm{E}$, and cholesterol: a dangerous liaison in Alzheimer's disease and other disorders. Prog Lipid Res 45: 73-90.

18. Carter CJ (2008) Interactions between the products of the Herpes simplex genome and Alzheimer's disease susceptibility genes: relevance to pathological-signalling cascades. Neurochem Int 52: 920-934.

19. Letenneur L, Pérès K, Fleury H, Garrigue I, Barberger-Gateau P, et al. (2008) Seropositivity to herpes simplex virus antibodies and risk of Alzheimer's disease: a population-based cohort study. PLoS One 3: e3637.

20. Kobayashi N, Nagata T, Shinagawa S, Oka N, Shimada K, et al. (2012) Increase in the IgG avidity index due to herpes simplex virus type 1 reactivation and its relationship with cognitive function in amnestic mild cognitive impairment and Alzheimer's disease. Biochem Biophys Res Commun.

21. Cribbs DH, Azizeh BY, Cotman CW, LaFerla FM (2000) Fibril formation and neurotoxicity by a herpes simplex virus glycoprotein $B$ fragment with homology to the Alzheimer's A beta peptide. Biochemistry 39: 5988-5994.

22. Shipley SJ, Parkin ET, Itzhaki RF, Dobson CB (2005) Herpes simplex virus interferes with amyloid precursor protein processing. BMC Microbiol 5: 48

23. De Chiara G, Marcocci ME, Civitelli L, Argnani R, Piacentini R, et al. (2010) APP processing induced by herpes simplex virus type 1 (HSV-1) yields several APP fragments in human and rat neuronal cells. PLoS One 5: e13989.

24. Wozniak MA, Itzhaki RF, Shipley SJ, Dobson CB (2007) Herpes simplex virus infection causes cellular beta-amyloid accumulation and secretase upregulation. Neurosci Lett 429: 95-100.

25. Satpute-Krishnan P, DeGiorgis JA, Bearer EL (2003) Fast anterograde transport of herpes simplex virus: role for the amyloid precursor protein of Alzheimer's disease. Aging Cell 2: 305-318.

26. Cheng SB, Ferland $P$, Webster $P$, Bearer EL (2011) Herpes simplex virus dances with amyloid precursor protein while exiting the cell. PLoS One 6: e17966.

27. Piacentini R, Civitelli L, Ripoli C, Marcocci ME, De Chiara G, et al. (2011) HHSV-1 promotes $\mathrm{Ca} 2+$-mediated APP phosphorylation and $A \beta$ accumulation in rat cortical neurons. Neurobiol Aging 32: 2323.

28. Wozniak MA, Frost AL, Itzhaki RF (2009) Alzheimer's disease-specific tau phosphorylation is induced by herpes simplex virus type 1 . J Alzheimers Dis 16: 341-350.

29. Wozniak MA, Frost AL, Preston CM, Itzhaki RF (2011) Antivirals reduce the formation of key Alzheimer's disease molecules in cell cultures acutely infected with herpes simplex virus type 1. PLoS One 6: e25152. 